\title{
NUTRITIONAL REPERCUSSIONS IN PATIENTS SUBMITTED TO BARIATRIC SURGERY
}

\author{
Repercussões nutricionais em pacientes submetidos à cirurgia bariátrica
}

\begin{abstract}
Sérgio SILVEIRA-JÚNIOR, Maurício Mendes de ALBUQUERQUE, Ricardo Reis do NASCIMENTO, Luisa Salvagni da ROSA, Daniel de Andrade HYGIDIO, Raphaela Mazon ZAPELINI
\end{abstract}

From the Serviço de Cirurgia do Aparelho Digestivo, Hospital Nossa Senhora da Conceição (Digestive Tract Surgery Department, Nossa Senhora da Conceição Hospital), Tubarão, SC, Brazil.

HEADINGS - Bariatric surgery. Nutrition, public health. Obesity.
ABSTRACT - Background: Few studies evaluated the association between nutritional disorders, quality of life and weight loss in patients undergoing bariatric surgery. Aim: To identify nutritional changes in patients undergoing bariatric surgery and correlate them with weight loss, control of comorbidities and quality of life. Method: A prospective cohort, analytical and descriptive study involving 59 patients undergoing bariatric surgery was done. Data were collected preoperatively at three and six months postoperatively, evaluating nutritional aspects and outcomes using BAROS questionnaire. The data had a confidence interval of $95 \%$. Results: The majority of patients was composed of women, $47(79.7 \%)$, with $55.9 \%$ of the series with BMI between 40 to $49.9 \mathrm{~kg} / \mathrm{m}^{2}$. In the sixth month after surgery scores of quality of life were significantly higher than preoperatively $(p<0.05)$ and $27(67.5 \%)$ patients had comorbidities resolved, 48 (81.3\%) presented BAROS scores of very good or excellent. After three and six months of surgery 16 and 23 presented some nutritional disorder, respectively. There was no relationship between the loss of excess weight and quality of life among patients with or without nutritional disorders. Conclusion: Nutritional disorders are uncommon in the early postoperative period and, when present, have little or no influence on quality of life and loss of excess weight.

\section{Correspondence:}

Sérgio Silveira Júnior

E-mail: raphamz@hotmail.com

Financial source: none

Conflicts of interest: none

Received for publication: 14/10/2014

Accepted for publication: 06/01/2015

DESCRITORES - Cirurgia bariátrica. Nutrição em saúde pública. Obesidade.
RESUMO - Racional: Poucos estudos avaliam a associação entre distúrbios nutricionais, qualidade de vida e perda de peso em pacientes submetidos à cirurgia bariátrica. Objetivo: Identificar alterações nutricionais em pacientes submetidos à cirurgia bariátrica e correlacioná-las com perda de peso, controle de comorbidades e qualidade de vida. Método: Estudo de coorte, prospectivo, analítico e descritivo envolvendo 59 pacientes submetidos à cirurgia bariátrica. Os dados foram coletados no pré-operatório e aos três e seis meses pós- operatórios, quantificando aspectos nutricionais e utilizando o Bariatric Analysis and Reporting Outcomes System (BAROS) como ferramenta de sucesso. Os dados usaram intervalo de confiança de $95 \%$. Resultados: O total de mulheres foi 47 (79,7\%), sendo 55,9\% com IMC entre $40-49,9 \mathrm{~kg} / \mathrm{m}^{2}$. No sexto mês depois da operação os escores de qualidade de vida foram significativamente maiores do que no pré-operatório $(p<0,05)$ e $27(67,5 \%)$ pacientes tinham todas comorbidades resolvidas, $48(81,3 \%)$ apresentaram conceito BAROS muito bom ou excelente. Após três e seis meses 16 e 23 pacientes apresentaram algum distúrbio nutricional, respectivamente. Não houve relação entre a perda do excesso de peso e qualidade de vida entre pacientes com ou sem distúrbio nutricional. Conclusão: os distúrbios nutricionais são pouco frequentes no pósoperatório precoce e, quando presentes, têm pouca ou nenhuma influência na qualidade de vida e na perda do excesso de peso.

INTRODUCTION

T he major problems of obesity are the associated comorbidities, such as hypertension, type 2 diabetes mellitus, cardiovascular diseases, alterations in the lipid profile and muscle skeletal disorders ${ }^{16}$.

Surgical treatment is the most efficient way to control morbid obesity ${ }^{23}$, because it makes possible to lose a big amount of weight and preserve the low weight ${ }^{17}$. The Roux-en-Y Gastric Bypass (RYGB) is the most performed operation in Brazil, and from the several techniques and procedures, it corresponds to more than $80 \%$; even though, the procedures using adjustable gastric bands are becoming more common ${ }^{2}$. Due to the increase in the number of bariatric surgeries, the complications have become more evident in the last years. From these, the deficiency of albumin, ferritin, vitamins and micronutrients must be detached.

There are many ways to evaluate results, among them the BAROS and the MoorheadArdelt quality of life questionnaire II, which is also included in BAROS $10,13,14,15,19,22$.

It is noticeable that there are not many publications in the literature discussing the association between nutritional disorders and quality of life with weight loss, 5,21 . So, this study aims to investigate the nutritional disorders in patients submitted to bariatric surgeries and its connections with weight loss and quality of life. 
METHODS

This study was approved by the Ethical Committee Research under the registration 12.243.4.01III. Data were obtained after the concordance of all the patients, by signing a Consent Term, in which they accepted to participate of this study, and all of them were 18 years old or older.

It is a prospective cohort study, performed with patients who were submitted to a surgery for obesity in the Digestive Tract Surgery Department of Nossa Senhora da Conceição Hospital, Tubarão, SC, Brazil, from July 2012 to December 2012.

The surgical technique of RYGB was performed with a proximal stomach pouch measuring $4 \mathrm{~cm}$ in the small curvature in which was possible to fit $70 \mathrm{ml}$, calibrated with a Fouchet 34 catheter and the anastomoses was calibrated with $12 \mathrm{~mm}$. The gastric limb measured around $80 \mathrm{~cm}$ and the biliopancretic $100 \mathrm{~cm}$; the food flow of the intestine was anastomosed to the stomach by pre-colonic via. Both were mechanic anastomoses done with a linear stapler, with reinforcement by two continuous suture lines with polidioxanona 3.0 thread. Routinely the mesenteric openings were shutdown when performed.

The post-operatory reviews were done in one, three and six months after the surgery and then they were scheduled according to the clinical necessity; however, they varied on each four months.

During the postoperative period, all the patients used multivitamin twice daily. As for vitamin $\mathrm{D}$ contents, patients have started to take it with level minor than $30 \mathrm{pmol} / \mathrm{l}$ to get their parathyroid hormone serum levels under $35 \mathrm{pg} /$ $\mathrm{ml}$. The treatment to the decrease of B12 vitamin started when patients' levels were minor than $350 \mathrm{pg} / \mathrm{ml}$, it was done by an intramuscular B complex injection once a month. All these recommendations were based on the Endocrine Society Guide, which gives directions to follow the patients and to handle their nutritional disorders after the bariatric surgeries ${ }^{9}$. One patient would be considered anemic when its hemoglobin was under $12,8 \mathrm{~g} / \mathrm{dl}$.

Data collection were divided in three periods: perioperative, at the third, and at the sixth months after the operation.

In the perioperative period, before the surgery, the following data were collected: age, gender, weight, BMI, comorbidities, medications in use, answer of the MooreheadArdelt II quality of life questionnaire; also were collected details of surgical procedure: surgery information, hospitalization

TABELA 2 - Degree of resolution of comorbidities (n/\%) time, surgery time, any operation associated, type of gastroplasty, perioperative complications and re-operations.

In the third month after the surgery, were documented the B12 vitamin levels, total serum proteins and its fractions, ferritin and the patients were submitted to the BAROS.

At the end of the sixth month were collected: total proteins and its fractions, B12 vitamin and a new BAROS.

For the results, patients were classified in five groups: failure, flaw, good, very good, excellent.

\section{Data analysis}

Data were typed in the software Epinfo 3.5.3 and analyzed in the software SPSS v.20.0. The variables were described by Mean and Standard Deviation to the quantitative variations and absolute and relative frequencies to the qualitative variables. The statistical tests were the chi-square or the $T$ test according to the need. The significance level adopted was $95 \%$.

\section{RESULTS}

Were operated 67 patients, but eight were excluded according to exclusion criteria; so, were enroll 59 in final account. From these, 47 (79,7\%) were women, 43 (72,9\%) were married at the moment of data collection and there was a mean of age of 37,8 years old.

Major of obese in the preoperative period had BMI between 40 to $49,9 \mathrm{~kg} / \mathrm{m}^{2}$, as shown in Table 1 . It has also been demonstrated that the mean of weight excess among men was significantly bigger than among women.

TABLE 1 - Sample distribution according to gender, BMI and mean of \%WE

\begin{tabular}{|c|c|c|c|}
\hline BMI & Men & Women & Total \\
\hline & $\mathrm{n} / \% /$ mean of $\% \mathrm{WE}$ & $\mathrm{n} / \% /$ mean of $\% \mathrm{WE}$ & $\mathrm{n} / \% /$ mean of $\% \mathrm{WE}$ \\
\hline $\begin{array}{c}35 \text { to } \\
39,9\end{array}$ & 2 / 16,7\% / 164,2 & 20 / 42,6\% / 167,9 & $22 / 37,3 \% / 167,6$ \\
\hline $\begin{array}{c}40 \text { to } \\
49,9\end{array}$ & $8 / 66,7 \%$ / 196 & $25 / 53,2 \% / 192,7$ & $33 / 55,9 \% / 193$ \\
\hline $\begin{array}{c}50 \text { to } \\
59,9\end{array}$ & $2 / 16,7 \% / 250,8$ & $2 / 4,3 \% / 236,4$ & $4 / 6,8 \% / 243$ \\
\hline Total & 12 / 20,3\% / 199,9 & 47 / 79,7\% / 184 & 59 / 100\% / 187,3 \\
\hline
\end{tabular}

Forty individuals had any kind of comorbidities in the preoperative interview. Table 2 shows that diabetes mellitus was

\begin{tabular}{|c|c|c|c|c|c|c|c|}
\hline & Total & \multicolumn{2}{c}{ Not resolved } & \multicolumn{2}{c|}{ Partly resolved } & \multicolumn{2}{c|}{ Fully resolved } \\
\hline & & $3^{\text {rd }}$ month & $6^{\text {th }}$ month & $3^{\text {rd }}$ month & $6^{\text {th }}$ month & $3^{\text {rd }}$ month & $6^{\text {th }}$ month \\
\hline Diabetes mellitus & $9 / 22,5 \%$ & - & - & $3 / 33,3 \%$ & $2 / 22,2 \%$ & $6 / 66,7 \%$ & $7 / 77,8 \%$ \\
\hline Hipertension & $26 / 65 \%$ & $3 / 11,5 \%$ & $1 / 3,8 \%$ & $6 / 23,1 \%$ & $6 / 23,1 \%$ & $17 / 65,4 \%$ & $19 / 73,1$ \\
\hline $\begin{array}{c}\text { Dyslipidemia } \\
\text { Sleep apnea }\end{array}$ & $10 / 25 \%$ & - & - & - & - & $10 / 25 \%$ & $10 / 25 \%$ \\
\hline $\begin{array}{c}\text { Arthrosis } \\
\text { Lower extremities }\end{array}$ & $7 / 10 \%$ & - & - & $3 / 75 \%$ & $1 / 25 \%$ & $1 / 25 \%$ & $3 / 75 \%$ \\
\hline $\begin{array}{c}\text { venous stasis } \\
\text { Reflux disease }\end{array}$ & $1 / 17,5 \%$ & - & - & $3 / 43 \%$ & $3 / 43 \%$ & $4 / 57 \%$ & $4 / 57 \%$ \\
\hline
\end{tabular}

TABLE 3 - Quality of life distribution in the pre and postoperative periods according to the Moorehead-Ardelt II questionnaire

\begin{tabular}{|c|c|c|c|c|c|c|}
\hline Quality of life & Variation & $\begin{array}{c}\text { Pre-op } \\
\text { mean }\left(\mathrm{SD}^{\star}\right)\end{array}$ & $\begin{array}{l}3^{\text {rd }} \text { month } \\
\text { mean (SD) }\end{array}$ & $\begin{array}{l}6^{\text {th }} \text { month } \\
\text { mean (SD) }\end{array}$ & $\begin{array}{c}\text { Difference } \\
6^{\text {th }} \mathrm{M}-\text { Pre-op }\end{array}$ & $p$ \\
\hline Self-esteem & $-0,5$ a 0,5 & $0,11( \pm 0,28)$ & $0,41( \pm 0,11)$ & $0,43( \pm 0,10)$ & 0,32 & 0,00 \\
\hline Physical activity & $-0,5$ a 0,5 & $-0,05( \pm 0,31)$ & $0,17( \pm 0,26)$ & $0,24( \pm 0,23)$ & 0,29 & 0,00 \\
\hline Social contacts & $-0,5$ a 0,5 & $0,22( \pm 0,25)$ & $0,41( \pm 0,12)$ & $0,42( \pm 0,13)$ & 0,20 & 0,00 \\
\hline Work & $-0,5$ a 0,5 & $0,19( \pm 0,28)$ & $0,39( \pm 0,14)$ & $0,42( \pm 0,13)$ & 0,23 & 0,00 \\
\hline Sexual activity & $-0,5$ a 0,5 & $0,13( \pm 0,32)$ & $0,31( \pm 0,26)$ & $0,33( \pm 0,25)$ & 0,20 & 0,00 \\
\hline Food & $-0,5$ a 0,5 & $0,04( \pm 0,23)$ & $0,38( \pm 0,14)$ & $0,42( \pm 0,10)$ & 0,38 & 0,00 \\
\hline Total & -3 a 3 & 0,66 & 2,1 & 2,28 & 1,62 & 0,00 \\
\hline
\end{tabular}

*SD=standard deviation 
totally solved in $77,8 \%$ of the patients after six months, it also demonstrates the degree of resolution of other comorbidities.

Table 3 shows the scores obtained in the MoorheadArdelt II Quality of Life questionnaire, discriminating the six different issues. Scores were all progressively bigger in the two postoperative moments, comparing to the preoperative ones. In the sixth month, all the issues' scores were significantly bigger when comparing to the preoperative period $(p<0,05)$.

Fifteen patients $(25,4 \%)$ had lost $50 \%$ or more of their weight excess by the end of the third month and 50 (85,7\%) by the end of the sixth month. Also, by the end of the sixth month $27(67,5 \%)$ had all the major comorbidities considered resolved (Table 4).

TABLE 4 - Patient distribution according to their punctuation at BAROS system in the third and sixth months after the surgery

\begin{tabular}{|c|c|c|c|c|}
\hline \multirow[b]{2}{*}{ I. $\%$ of wight excess loss } & \multicolumn{2}{|c|}{$3^{\text {rd }}$ month } & \multicolumn{2}{|c|}{$6^{\text {th }}$ month } \\
\hline & $\mathrm{N}$ & $\%$ & $\mathrm{~N}$ & $\%$ \\
\hline Weight gain $(-1)^{*}$ & - & & - & \\
\hline $0-24(0)^{*}$ & 1 & 1,7 & - & \\
\hline $25-49(1)^{*}$ & 43 & 72,9 & 9 & 15,3 \\
\hline $50-74(2)^{\star}$ & 15 & 25,4 & 43 & 72,9 \\
\hline $75-100(3)^{\star}$ & - & & 7 & 11,9 \\
\hline Total & 59 & & 59 & \\
\hline \multicolumn{5}{|l|}{ II. Comorbidities control } \\
\hline Aggravated $(-1)^{*}$ & 0 & 0 & 0 & 0 \\
\hline Unchanged $(0)^{*}$ & 5 & 12,5 & 3 & 7,5 \\
\hline Improved $(1)^{*}$ & 7 & 17,5 & 5 & 12,5 \\
\hline One > resolved $(2)^{*}$ & 8 & 20 & 5 & 12,5 \\
\hline All > resolved $(3)^{*}$ & 20 & 50 & 27 & 67,5 \\
\hline No comorbidities & 19 & & 19 & \\
\hline Total & 59 & & & \\
\hline
\end{tabular}

Figure 1 shows that the BAROS final concept had a progressive improve when comparing the third and the sixth months; in the third, 33 patients $(55,9 \%)$ presented a very good or excellent concept; and by the end of the sixth month, 48 patients $(81,3 \%)$ presented the same concept.

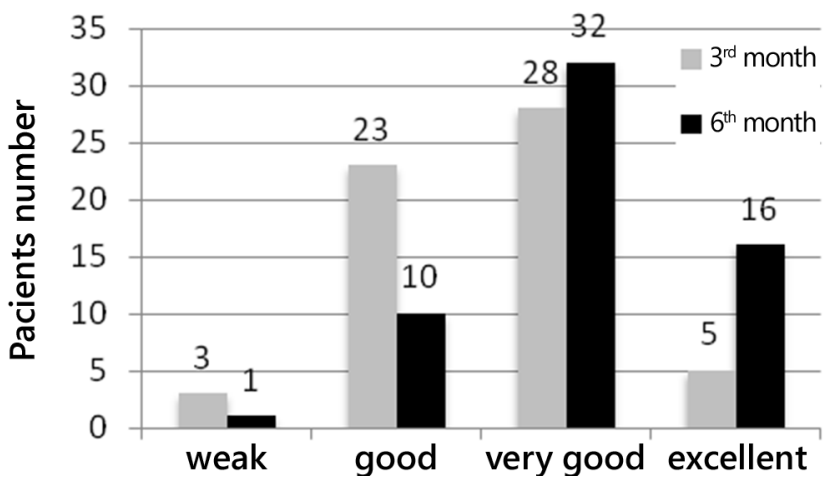

FIGURE 1 - BAROS score distribution according to the patient numbers

Only one patient filled criteria for immediate postoperative complications, because of dehiscence and deep venous thrombosis. This same individual was the only one who needed to go over a second surgery.

Table 5 clarifies the prevalence of nutritional disorders; it is noticed that the vitamin $D$ deficiency by the end of the third month occurred in three patients $(5,1 \%)$; by the end of the sixth month there were $9(15,3 \%)$ patients in this situation. The protein deficiency was the same in both periods evaluated. B12 vitamin deficiency was bigger in the third month after the surgery $(5,1 \%)$ when comparing to the sixth month $(1,7 \%)$. Calcium deficiency was present in $3,4 \%$ and $5,1 \%$ respectively in the third and sixth month after the surgery. Anemia was present in $6,8 \%$ of patients three months after and $13,6 \%$ in six months. It has not been evidenced ferritin deficiency.

TABLE 5 - Nutritional disorders prevalence

\begin{tabular}{|c|c|c|}
\hline Deficiency & $3^{\text {rd }}$ month postoperative & $6^{\text {th }}$ month postoperative \\
\hline Proteins & $6 / 10,2 \%$ & $6 / 10,2 \%$ \\
\hline B 12 Vitamin & $3 / 5,1 \%$ & $1 / 1,7 \%$ \\
\hline Ferritin & 0 & 0 \\
\hline D Vitamin & $3 / 5,1 \%$ & $9 / 15,3 \%$ \\
\hline Calcium & $2 / 3,4 \%$ & $3 / 5,1 \%$ \\
\hline Anemia & $4 / 6,8 \%$ & $8 / 13,6 \%$ \\
\hline
\end{tabular}

Table 6 shows that there was no significant difference in the overweight loss percentage $(\% \mathrm{OL})$ among patients with or without a nutritional disorder; it also demonstrates that the quality of life score in patients with a nutritional disorder improves from the third to the sixth month and it does not change among patients without a nutritional disorder. In the third month after the surgery, 16 patients presented any kind of nutritional disorder and 43 did not. At the end of the six months, 23 patients had any nutritional disorder and 36 did not.

TABLE 6 -Overweight loss percentage and quality of life analysis relating to the presence of nutritional disorders in the third and sixth months after the surgery

\begin{tabular}{|c|c|c|c|c|c|c|}
\hline & \multicolumn{3}{c}{$3^{\text {rd }}$ month } & \multicolumn{3}{c|}{$6^{\text {th }}$ Month } \\
\hline & $\begin{array}{c}\text { With ND } \\
(n=16)\end{array}$ & $\begin{array}{c}\text { Without ND } \\
(n=43)\end{array}$ & $p$ & $\begin{array}{c}\text { With ND } \\
(n=23)\end{array}$ & $\begin{array}{c}\text { Without ND } \\
(n=36)\end{array}$ & $P$ \\
\hline $\begin{array}{c}\text { \%OLP } \\
\text { (mean/SD) }\end{array}$ & $\begin{array}{c}42,9 \\
( \pm 10,9)\end{array}$ & $\begin{array}{c}43,9 \\
( \pm 8,01)\end{array}$ & 0,70 & $\begin{array}{c}60,9 \\
( \pm 10,6)\end{array}$ & $\begin{array}{c}61,9 \\
( \pm 13,2)\end{array}$ & 0,77 \\
\hline $\begin{array}{c}\text { QoL } \\
\text { (mean/SD) }\end{array}$ & $\begin{array}{c}1,8 \\
( \pm 0,92)\end{array}$ & $\begin{array}{c}2,21 \\
( \pm 0,71)\end{array}$ & 0,12 & $\begin{array}{c}2,41 \\
( \pm 0,71)\end{array}$ & $\begin{array}{c}2,21 \\
( \pm 0,53)\end{array}$ & 0,21 \\
\hline
\end{tabular}

$\mathrm{ND}=$ nutritional disorder; $\mathrm{SD}=$ standard deviation; $\mathrm{QoL}=$ quality of life - Morehead Ardel II questionnaire

\section{DISCUSSION}

This study has been limited to the presence of some nutritional parameters among patients submitted to gastroplasty. It has not aimed an extensive and detailed analysis of micro and macronutrients of an individuals' diet.

As it is observed in the national and international studies, there was a significant higher prevalence among women. A North-American study involving 700 patients submitted to the RYGB had a female prevalence of $82 \%$. Studies have demonstrated that in Brazil the female prevalence is between $71-80 \%^{1,4}$. In this study the female prevalence was $72,9 \%$. However, the obesity prevalence among Brazilian population, according to the Brazilian Society of Bariatric and Metabolic Surgery was estimated in 18\% among women and in 13\% among men ${ }^{24}$. Even though obesity is more frequent among women than among men, this difference is not so significant when comparing with the operated patients. These evidences show that the search for a surgical treatment of obesity is higher among women then among men $^{18}$.

About age, this study has been very close to most of the studies available in the literature. In this research, the mean of age was 37,8 years old. As the Brazilian Society of Bariatric and Metabolic Surgery shows, when sum the overweight and obese patients it is noticeable that most of them is between 18-25 years old, different of the mean of age that generally the patients submit to the surgery. Other studies have demonstrated similar data, possibly representing a late search for the surgical treatment, after frustrated tries of losing weight by clinical methods $3,6,24$.

In this study, it has been demonstrated that $55,9 \%$ of patients had preoperative BMI between $40-49,9 \mathrm{~kg} / \mathrm{m}^{2}$, 
agreeing with the study by Blume et al. ${ }^{3}$ in which the mean of BMI was $48,8 \mathrm{~kg} / \mathrm{m}^{2}$ and with another research that obtained a mean of $45,2 \mathrm{~kg} / \mathrm{m}^{2}$. Most of obese who are submitted to the operation, follow the formal indications: BMI bigger or equal to $40 \mathrm{~kg} / \mathrm{m}^{2}$ or BMI between $35-39,9 \mathrm{~kg} / \mathrm{m}^{2}$ associated to one comorbidity $3,11,25$.

An important factor to be evaluated is the overweight loss percentage after the operation. Welch et al. ${ }^{26}$ related that after two years and a half, the patients presented a $\%$ OL of $59,1 \%$; also, $70,8 \%$ had lost at least $50 \%$ of their overweight. Other studies, also following patients for two years demonstrated that the biggest mean of $\% \mathrm{OL}$ was at the $18^{\text {th }}$ month, with a value of $75,3 \%$ and $73,2 \%{ }^{1,26}$. Brazilian studies have showed that six months after the RYGB the mean of $\% \mathrm{OL}$ was $58,3 \% 3,25$. In this study, by the end of six months, $84,7 \%$ had lost $50 \%$ or more of their overweight. According to the current recommendations, it is considered surgery success when there is a \%OL bigger than $50 \%$ after the surgery. It is observed that the overweight loss of this research's patients has been above average and occurred earlier when comparing to the literature.

About comrbodities, Blume et al. ${ }^{3}$ demonstrated the presence of diabetes mellitus in $14,7 \%$ in the preoperative period and only $1,8 \%$ still had that disorder six months after the surgery; in another study, 19\% of obese presented it before the surgery and $83 \%$ solved this comorbidity after the surgery ${ }^{3,7}$. About hypertension, $45 \%$ of patients had this disease before the surgery, but $87 \%$ of them demonstrated to be healed from it after the surgery ${ }^{3,7}$. Aforementioned data are close to the values found by this study, demonstrating that the obesity surgery improves the patients from the most prevalent comorbidities.

BAROS is very useful advice to global evaluate the results of the obesity surgery, because it evaluates plenty factors. Prazeres et al. ${ }^{18}$ in their study involving 66 patients showed that in the period between six and eighteen months, $67 \%$ of the patients presented a "good" score. In another study involving 684 patients, after six months, $50 \%$ of presented a "good" score and 32\% "very good". Prevedello et al. ${ }^{19}$ showed that the end thirty months $21,9 \%$ of the patients had an "excellent" score and 50\% "very good"18,19. In this research, $81,3 \%$ of the operated patients already presented a score "very good" or "excellent" six months after the surgery and only one patient presented a "weak" score. This result is very satisfactory when compared to recent publications, even more for knowing about the importance of BAROS as an advice to evaluate the result $\mathrm{t}^{1,18,19}$

About the nutritional disorders, there are plenty variations on talking about the deficiencies in the pre and postoperative periods. Moizé et al. ${ }^{12}$, in their research involving 231 patients, estimated that the protein and albumin deficiencies in the preoperative period was around $1,6 \%$ among the patients, the ferritin deficiency in $10,3 \%$ of the patients, B12 vitamin in 2,2\%, D vitamin in $67,7 \%$ and anemia in $22,2 \%$ of the patients. It contrasts to Ems et al. ${ }^{6}$ who demonstrated that the albumin deficiency in the preoperative period is in $12,5 \%$ of the patients, ferritin in $6,9 \%$, B12 vitamin in $18,1 \%$, D vitamin in $25,4 \%$ and anemia in $6,9 \%$ during the preoperative period ${ }^{6,12}$. This study did not aim to quantify the nutritional disorder in the preoperative period, even though some patients probably already had them and they may have been kept after the surgery for some reasons not related to the surgical procedure.

When talking about nutritional complications in the postoperative period it is noticed a change about its prevalence. After six months, a Brazilian study has showed that the albumin deficiency is present in $0,6 \%$ of the patients, ferritin in $4,1 \%$, anemia in $21,8 \%$ and B12 vitamin deficiency in $3,5 \%^{3}$. In another study, after one year, $4 \%$ of patients presented albumin deficiency, $15 \%$ ferritin, 30\% D vitamin and
$11 \%$ B12 vitamin ${ }^{25}$. To prove the big variation of nutritional disorders in the postoperative period, a North-American revision study published in 2013 pointed that the prevalence of B12 vitamin deficiency varies from $4-62 \%$ and the $D$ vitamin deficiency prevalence goes from $7-60 \%{ }^{20}$. In this study, it has not been evidenced ferritin deficiency; only $1,7 \%$ of the patient presented B12 vitamin deficiency and 13,6\% had anemia. All the values cited were measured six months after the surgery. It is worth to detach that there was a low prevalence of nutritional disorders in the postoperative period of this sample when comparing to other national and international studies.

It is noticeable that there is no patron in the literature about nutritional deficiency in pre and postoperative periods. It was usual to deduce that with the surgery and the functional anatomic alteration - with a potential absorptive deficit in the gastrointestinal tract -, most of the nutritional deficiencies would be present in the postoperative period. However, this thought has not been proved by the literature and it has been evidenced that many patients when go through the surgery already have some kind of deficiency. The most important thing to notice is that there was no significant difference of \%OL neither of quality of life between the patients with a nutritional disorder and those who did not present these deficiencies. This data disagrees with the sentence: as bigger the weight loss, bigger the nutritional disorder and that the nutritional deficiencies could be related to a worse quality of life ${ }^{18}$.

\section{CONCLUSION}

Nutritional disorders are not frequent in early postoperative period of RYGB. When present, they are shortly or not related to patients' quality of life and overweight loss.

REFERENCES

1. Al Harakeh AB, Larson CJ, Mathiason MA, Kallies KJ, Kothari SN BAROS results in 700 patients after laparoscopic Roux-en-Y gastric bypass with subset analysis of age, gender, and initial body mass index. Surgery for Obesity and Related Diseases. 2011; 7(1):94-98.

2. Angrisani L, Lorenzo M, Borrelli V. Laparoscopic adjustable gastric banding versus Roux-en-Y gastric bypass: 5 -year results of a prospective randomized trial [with discussion]. Surg Obes Relat Dis. 2007; 3:127-133.

3. Blume C, Boni CC, Casagrande S, Rizzolli J, Vontobel AP, Mottin CC. Nutritional Profile of Patients Before and After Roux-en-Y Gastric Bypass: 3-Year Follow-up. Obes Surg. Nov.2012; 22(11):1676-85.

4. Costa CC, Ivo ML, Cantero WB, Tognini JRs. Obesidade em pacientes candidatos a cirurgia bariátrica. Actapaul. enferm. Fev.2009; 22(1):55-59.

5. Costa LD, Valezi AC, Matsuo T, Dichi I, Dichi JB. Repercussão da perda de peso sobre parâmetros nutricionais e metabólicos de pacientes obesos graves após um ano de gastroplastia em Y-de-Roux. Rev. Col. Bras. Cir. 2010; 37(2): 096-101

6. Ernst B, Thurnheer M, Sebastian M, Bernd S. Evidence for the Necessity to Systematically Assess Micronutrient Status Prior to Bariatric Surgery. ObesSurg. 2009; 19:66-73.

7. Higa K, Ho T, Tercero F, Yunus T, Boone K. Laparoscopic Roux-en-Y gastric bypass: 10-year follow-up. Surgery for Obesity and Related Diseases. 2011;7:516-525.

8. Jóia-Neto L, Lopes-Junior AG, Jacob CE. Alterações metabólicas e digestivas no pós-operatório de cirurgia bariátrica. $A B C D$, arq. bras. cir. dig., 2010;23(4):266-269

9. Journal of Clinical Endocrinology \& Metabolism, November 2010; 95(11):4823-4843.

10. Marchesini JB, Nicareta JR. Comparative study of five different surgical techniques for the treatment of morbid obesity using BAROS. ABCD, arq. bras. cir. dig. 2014; 27(suppl.1):17-20.

11. Mitka M. Surgery for obesity: demand soars amid scientific, ethical questions. JAMA 2003;289:1761-2. 
12. Moizé V, Deulofeu R, Torres F, Martinez J, Vidal J. Nutritional Intake and Prevalence of Nutritional Deficiencies Prior to Surgery in a Spanish Morbidly Obese Population. Obes Surg. 2011;21:13821388.

13. Myers JA, Clifford JC, Sarker S, Primeau M, Doninger GL, Shayani V. Quality of life after laparoscopic adjustable gastric banding using the Baros and Moorehead-Ardelt quality of life questionnaire II. JSLS.2006; 10:414-420.

14. Oria HE, Moorehead MK. Bariatric analysis and reporting outcome system (BAROS). Obes Res 1998; 8: 487-499.

15. Oria HE, Moorehead MK. Updated bariatric analisys and reporting outcome system (BAROS). Surgery for Obesity and Related Diseases. 2009; (5):60-66.

16. Pi-Sunyer FX. The obesity epidemic: pathophysiology and consequences of obesity. Obes Res 2002; 10(suppl.2): 97S-104S

17. Pi-Sunyer, FX. Health implications of obesity. Am. J. Clin. Nutr., v.53, supl.6, p.1595-1603, jun. 1991.

18. Prazeres P, Alves S, Yandara CS, Arruda MM. Eating habits, nutritional status and quality of life of patients in late postoperative gastric bypass Roux-Y.Nutr Hosp. 2013; 28(3):637-642.

19. Prevedello CF, Colpo E, Mayer ET, Copetti H. Análise do impacto da cirurgia bariátrica em uma população do centro do estado do Rio Grande do Sul utilizando o método BAROS. Arq Gastroenterol. 2009; 46(3):199-203.
20. Saltzman E, Philip Karl J. Nutrient Deficiencies After Gastric Bypass Surgery. Annu. Rev. Nutr. 2013;33:183-203.

21. Silva LGO, Manso JEF, Silva RARN, Pereira SE, Sobrinho CJS, Rangel CW Relação entre o estado nutricional de vitamina a e a regressão da esteatose hepática após gastroplastia em Y- de- Roux para tratamento da obesidade classe III. ABCD, arq. bras. cir. dig. 2012;25(4):250-256

22. Silva PRB, Souza MR, Silva EM, Silva AS. Nutritional status and life quality in patients undergoing bariatric surgery. $A B C D$, arq. bras. cir. dig., 2014;27(Suppl. 1):35-38

23. Soares CC, Falcão MC. Abordagem nutricional nos diferentes tipos de cirurgia bariátrica. RevBrasNutrClin. 2007; 22(1): 59-64.

24. Sociedade Brasileira de Cirurgia Bariátrica e Metabólica.Disponível em: http://www.sbcb.org.br/obesidade.php?menu=4.Acesso em: jan. 2013.

25. Toh S, Zarshenas N, Jorgensen J. Prevalence of nutrient deficiencies in bariatric patients. Nutrition.2009; 25:1150-1156.

26. Welch G, Wesolowski C, Zagarins S, Kuhn J., Romanelli J., Garb J., Allen N. Evaluation of Clinical Outcomes for Gastric Bypass Surgery: Results from a Comprehensive Follow-up Study. Obes Surg. 2011; 21:18-28. 